\title{
Pengaruh model pembelajaran kooperatif tipe the power of two terhadap hasil belajar matematika siswa SMP Negeri 3 Mataram
}

\author{
Nunung Rusdiyawanti ${ }^{*}$, Nurul Hikmah², Syahrul Azmi², Laila \\ Hayati $^{2}$
}

${ }^{1}$ Mahasiswa Pendidikan Matematika, FKIP, Universitas Mataram, Mataram

${ }_{2}^{2}$ Pendidikan Matematika, FKIP, Universitas Mataram, Mataram

rusdiyawanti10@gmail.com

Diterima: 11 Juni 2021; Direvisi: 29 Juni 2021; Dipublikasi: 30 Juni 2021

\begin{abstract}
This study aims to determine the influence of cooperative learning method type of the power of two on mathematics learning achievement of VIII grade students of SMP Negeri 3 Mataram academic year 2019/2020. This study used quasy experimental design. Population in this study consist all of VIII grade student from 7 class and 2 class as sample by using Cluster random sampling. The data collecting technique is using essay. Data analysis technique using t test to determine the influenceof the power of two cooperative learning method on mathematics learning achievement of VIII grade students of SMP Negeri 3 Mataram academic year 2019/2020. For the experimental class it is applied using the cooperative learning model type the power of two and for the control class it is applied using the direct learning model. Based on data analysis, mathematics learning achievement student that used cooperative learning method type of the power of two is higher than students that used conventional learning method. This indicates that there is an influence of the type the power of two cooperative learning methodon mathematics learning achievement of VIII grade students of SMP Negeri 3 Mataram academic year 2019/2020.
\end{abstract}

Keywords: Cooperative Learning Method; The Power of Two Type; Mathematics Learning Achievement

\begin{abstract}
Abstrak
Penelitian ini bertujuan untuk mengetahui pengaruh model pembelajaran kooperatif tipe the power of two terhadap hasil belajar matematika siswa kelas VIII SMP Negeri 3 Mataram tahun pelajaran 2019/2020. Pendekatan kuantitatif dalam penelitian ini adalah quasi eksperimen. Populasi pada penelitian ini seluruh siswa kelas VIII yang tersebar dari tujuh kelas dan sampel dari dua kelas diambil dengan teknik cluster random sampling. Teknik pengumpulan data menggunakan tes dan non tes. Teknik analisis data yang digunakan adalah uji t untuk mengetahui pengaruh model pembelajaran kooperatif tipe the power of two terhadap hasil belajar matematika siswa kelas VIII SMP Negeri 3 Mataram tahun pelajaran 2019/2020. Untuk kelas eksperimen diterapkan menggunakan model pembelajaran kooperatif tipe the power of two dan untuk kelas kontrol diterapkan menggunakan model pembelajaran langsung. Berdasarkan analisis data deskriptif diperoleh rata-rata hasil belajar siswa yang diajar dengan menggunakan model pembelajaran kooperatif tipe the power of two lebih baik dibanding dengan menggunakan model pembelajaran langsung. Hal tersebut mengindikasikan bahwa terdapat pengaruh model pembelajaran kooperatif tipe the power of two terhadap hasil belajar matematika siswa kelas VIII SMP Negeri 3 Mataram tahun pelajaran 2019/2020.
\end{abstract}

Kata Kunci: Model Pembelajaran Kooperatif; Tipe The Power of Two; Hasil Belajar Matematika 


\section{PENDAHULUAN}

Upaya untuk mencapai tujuan pembelajaran terus dilakukan dalam semua bidang ilmu pengetahuan terutama dalam bidang matematika. Pemerintah melakukan berbagai usaha untuk meningkatkan mutu pendidikan matematika, misalnya dengan penyempurnaan kurikulum. Namun seiring dengan usaha pemerintah tersebut, kenyataanya menyatakan bahwa mutu pendidikan khususnya pendidikan maatematika kurang baik bahkan bisa dikatakan rendah. Pada kenyataanya pelajaran matematika masih dianggap sulit oleh siswa di sekolah (Siregar, 2017).

Berdasarkan hasil wawancara dengan salah satu guru matematika kelas VIII di SMP Negeri 3 Mataram tanggal 10 september 2019 menyatakan bahwa kurangnya minat belajar matematika, siswa kurang aktif dalam mengikuti proses pembelajaran, siswa tidak terlalu mendengarkan intruksi dari guru, siswa lebih sering berbicara dengan teman sebangkunya dan siswa tidak memperhatikan penjelasan guru, sehingga menyebabkan tujuan pembelajaran belum tercapai secara optimal. Dalam pembelajaran, guru masih menggunankan model pembelajaran langsung dimana, saat pembelajaran guru lebih aktif menjelaskan sehingga siswa hanya mendengar, mencatat, dan mengerjakan latihan soal. Hal itu mengakibatkan kurangnya interaksi antar siswa, dan dapat dikatakan siswa kurang aktif dalam proses pembelajaran.

Umumnya guru mengajar menggunakan model pembelajaran langsung yaitu guru masih lebih dominan dari pada siswa. Karena siswa sering berbicara dengan teman sebangkunya dan jarang memperhatikan penjelasan guru maka, penelitiakan mencoba memfasilitasi siswa untuk berdiskusi dengan membentuk kelompok-kelompok kecil sehingga dapat melatih dan memacu siswa untuk terlibat secara aktif dalam kegiatan pembelajaran dan diharapkan dapat membantu siswa dalam memahami materi pembelajaran. Model pembelajaran yang cocok untuk memfasilitasi siswa dalam belajar kelompok yang heterogen adalah model pembelajaran kooperatif tipe the power of two.

Pembelajaran kooperatif merupakan metode pengajaran dimana para siswa bekerja dalam kelompok-kelompok kecil dengan tingkat kemampuan yang berbeda-beda (Slavin, 2005). Menurut Daryanto dan Rahardjo model pembelajaran kooperatif merupakan suatu model pembelajaran yang mengutamakan adanya kelompok-kelompok. Setiap siswa yang ada dalam kelompok-kelompok mempuyai tingkat kemapuan yang berbeda-beda (tinggi, sedang dan rendah) dan jika memungkinkan anggota kelompok berasal dari ras, budaya, suku yang berbeda serta memperhatikan kesetaraan jender (Daryanto \& Rahardjo, 2012). Model pembelajaran kooperatif tipe the power of two mempuyai prinsip yaitu dua kepala lebih baik dari pada satu kepala, maksudnya yaitu berpikir berdua jauh lebih baik dari pada berpikir sendiri dan merupakan kegiatan belajar yang dapat meningkatkan aktivitas pembelajaran (Silberman, 2014). 
Berdasarkan uraian di atas, maka penelitian ini bertujuan untuk mengetahui pengaruh model pembelajaran kooperatif tipe the power of two terhadap hasil belajar matematika siswa kelas VIII SMP Negeri 3 Mataram tahun pelajaran 2019/2020.

\section{METODE PELAKSANAAN}

Jenis penelitian yang digunakan dalam penelitian ini adalah quasi eksperimen dengan desain posttest Only Non-Equivalen Control Group Design. Penelitian ini dilaksanakan di SMP Negeri 3 Mataram pada semester genap tahun pelajaran 2019/2020. Variabel dalam penelitian ini berupa variabel bebas dan variabel terikat. Variabel bebas dalam penelitian ini adalah pengaruh model pembelajaran kooperatif tipe the power of two, sedangkan variabel terikatnya adalah hasil belajar matematika siswa kelas VIII SMP Negeri 3 Mataram tahun pelajaran 2019/2020.

Populasi penelitian ini yaitu seluruh siswa kelas VIII SMP Negeri 3 Mataram tahun pelajaran 2019/2020 yang berjumlah 222 siswa. Pengambilan sampel dilakukan dengan menggunakan teknik Cluster random sampling. Menurut Sanjaya cluster random sampling merupakan teknik pengambilan anggota sampel yang dilaksanakan berdasarkan gugus atau kelompok. Jadi pada cluster random sampling ini anggota sampel bukan individu-individu, melainkan kelompok individu-individu (Sanjaya, 2015). Variansi data siswa kelas VIII SMP Negeri 3 Mataram homogen. Dengan cara di undi dan terambilah kelas VIII-1 dan VIII-2 sebagai sampel penelitian.

Teknik pengumpulan data dalam penelitian ini adalah tes dan non tes. Tes dalam penelitian ini berupa soal hasil belajar matematika siswa dimana soal terdiri dari 3 soal uraian. Non tes dalam penelitian ini berupa lembar observasi untuk guru dan siswa. Teknik analisis data pada penelitian ini adalah analisis statistik deskriptif dan analisis statistik inferensial dengan uji t dua sampel independen. Sebelumnya dilakukan uji asumsi yaitu uji normalitas dan homogenitas setelahnya dilakukan uji t. Uji hipotesis dengan uji t untuk mengetahui perbedaan hasil belajar matematika siswa kelas VIII SMP Negeri 3 Mataram menggunakan model pembelajaran kooperatif tipe the power of two tahun pelajaran 2019/2020.

\section{HASIL DAN PEMBAHASAN}

\subsection{Hasil Penelitian}

Analisis statistik deskriptif untuk mendeskripsikan hasil belajar matematika siswa kelas VIII SMP Negeri 3 mataram. Adapun perhitungan statistik deskriptif hasil belajar adalah sebagai berikut.

Tabel 1. Hasil Analisis Deskriptif Data Hasil Posttest

\begin{tabular}{clcc}
\hline \multirow{2}{*}{ No } & \multicolumn{1}{c}{ Ukuran } & \multicolumn{2}{c}{ Kelas } \\
\cline { 3 - 4 } & & Eksperimen & Kontrol \\
\hline 1 & Jumlah Siswa & 32 & 32 \\
\hline 2 & Rata-rata & 60,22 & 48,50 \\
\hline 3 & Simpangan Baku (S) & 27,27 & 23,56 \\
\hline
\end{tabular}




\begin{tabular}{clcc}
\hline 4 & Nilai Tertinggi & 98 & 96 \\
\hline 5 & Nilai Terendah & 14 & 16 \\
\hline 6 & Ketuntasan Klasikal & $40,625 \%$ & $18,750 \%$
\end{tabular}

Berdasarkan hasil analisis deskriptif dapat dilihat bahwa prestasi belajar kelas eksperimen dan kelas kontrol belum mencapai KKM.

Selanjutnya dilakukan uji statistik inferensial yang dimulai dengan uji prasyarat terlebih dahulu.

\section{Uji Normalitas}

Tabel 2. Hasil Uji Normalitas Data Posttest

\begin{tabular}{|c|c|c|c|c|}
\hline Kelas & $L_{\text {hitung }}$ & $L_{\text {tabel }}$ & Keputusan uji & Kesimpulan \\
\hline $\begin{array}{l}\text { Eksperimen } \\
\text { (VIII-1) }\end{array}$ & 0,1217 & 0,1566 & \multirow{2}{*}{$L_{\text {hitung }}<L_{\text {tabel }}$} & \multirow{2}{*}{$H_{0}$ diterima } \\
\hline $\begin{array}{l}\text { Kontrol } \\
\text { (VIII-2) }\end{array}$ & 0,1321 & 0,1566 & & \\
\hline
\end{tabular}

Berdasarkan Tabel 2 hasil uji normalitas data posttest yang menggunakan uji liliefors terlihat hasil uji normalitas data kelas eksperimen dan kontrol memiliki nilai $L_{\text {hitung }}<$ $L_{\text {tabel }}$. Sehingga $H_{0}$ diterima, maka data dari nilai posttest matematika pada materi lingkaran kelas eksperimen dan kelas kontrol berasal dari populasi yang berdistribusi normal.

\section{Uji Homogenitas}

Tabel 3. Hasil Uji Homogenitas Data Posttest

\begin{tabular}{llllll}
\hline Kelas & Varians & $\chi^{2}{ }_{\text {hitung }}$ & $\chi_{\text {tabel }}^{2}$ & Keputusan Uji & Kesimpulan \\
\hline $\begin{array}{l}\text { Eksperimen } \\
\text { (VIII-1) }\end{array}$ & 743,4667 & & & & \\
$\begin{array}{l}\text { Kontrol } \\
\text { (VIII-2) }\end{array}$ & 555,1613 & & 3,841 & $\chi_{\text {hitung }}^{2}<\chi_{\text {tabel }}^{2}$ & $H_{0}$ diterima \\
\hline
\end{tabular}

Berdasarkan Tabel 3, terlihat hasil uji homogenitas menggunakan uji Barllet, kelas eksperimen dan kontrol memiliki nilai $\chi_{\text {nitung }}^{2}<\chi_{\text {tabel }}^{2}$. Sehingga $H_{0}$ diterima, maka data dari nilai posttest kelas eksperimen dan kelas kontrol memiliki variansi yang sama (homogen).

\section{Uji t}

Tabel 4. Hasil Uji-t Data Posttest

\begin{tabular}{lccccccl}
\hline Kelas & $\begin{array}{c}\text { Jumlah } \\
\text { Siswa }\end{array}$ & $\begin{array}{c}\text { Rata- } \\
\text { rata }\end{array}$ & Varians & $t_{\text {hitung }}$ & Taraf Sig & $t_{\text {tabel }}$ & Kesimpulan \\
\hline VIII-1 & 32 & 64,22 & 743,467 & 2,4678 & 0,05 & 1,6698 & $H_{0}$ ditolak \\
\hline VIII-2 & 32 & 48,50 & 555,163 & 2,05 & \\
\hline
\end{tabular}

Berdasarkan Tabel 4, terlihat hasil uji hipotesis diperoleh nilai $t_{\text {hitung }}>t_{\text {tabel }}$, maka $H_{0}$ ditolak. Sehingga, dapat disimpulkan rata-rata hasil belajar matematika kelas eksperimen yang menggunakan model pembelajaran kooperatif tipe the power of two lebih tinggi dari rata-rata hasil belajar matematika kelas kontrol yang menggunakan model pembelajaran langsung. Ini artinya penggunaan model 
pembelajaran kooperatif tipe the power of two berpengaruh terhadap hasil belajar matematika siswa kelas VIIIdi SMPNegeri 3 Mataram tahun pelajaran 2019/2020.

\subsection{Pembahasan}

Berdasarkan hasil penelitian pada analisis data deskriptif terlihat bahwa terdapat perbedaan antara hasil belajar siswa kelas eksperimen dan kelas kontrol. Kelas yang mendapat perlakuan menggunakan model pembelajaran kooperatif tipe the power of two memperoleh rata-rata hasil belajar yang lebih baik dibandingkan dengan hasil belajar sisiwa kelas kontrol yang mendapat perlakuan menggunakan model pembelajaran langsung. Secara deskriptif, perbedaan hasil belajar siswa dikarenakan pembelajaran dengan menggunakan model pembelajaran kooperatif tipe the power of two siswa lebih terlibat secara aktif dalam kegiatan belajar, siswa lebih berkesempatan ikut mengamati dan berfikir tentang bagaimana terbentuknya suatu konsep, merasakan adanya masaalah dan mengupayakan pemecahannya. Siswa lebih mengerti bagaimana mendapatkan definisi dan rumus sehingga siswa akan lebih menguasai materi. Siswa tidak mengggantungkan guru, akan tetapi dapat menambah kepercayaan kemampuan berfikir sendiri, menemukan informasi dari berbagai sumber dan belajar dari siswa lain,

Tidak begitu pada pembelajaran yang menggunakan model pembelajaran langsung, siswa lebih cenderung pasif, hanya menerima informasi dari guru sehingga siswa belajar menghafal dan akibatnya jika siswa lupa terhadap rumus atau definisi siswa tidak akan mampu mengkonstruksikan kembali rumus tersebut.

Dengan demikian pembelajaran dengan model pembelajaran kooperatif tipe the power of two berpengaruh terhadap hasil belajar matematika siswa kelas VIII SMP Negeri 3 Mataram tahun pelajaran 2019/2020. Kondisi pelajaran yang seperti inilah yang mampu membuat siswa lebih aktif sehingga proses pembelajaran dapat berjalan dengan baik dan hasil belajarnya juga baik.

Pembelajaran dengan model pembelajaran kooperatif tipe the power of two pada kelas eksperimen memiliki arti yang berbeda dengan cara pembelajaran yang berbeda pada kelas kontrol. Ternyata perbedaan ini menghasilkan rata-rata prestasi belajar yang berbeda pula. Jika kita melihat rata-rata kelas eksperimen yang menggunakan model pembelajaran kooperatif tipe the power of two memiliki rata-rata hasil belajar lebih tinggi dibandingkan dengan kelas kontrol yang menggunakan model pembelajaran langsung. Hal ini menunjukkan bahwa pembelajaran yang menggunakan model pembelajaran kooperatif tipe the power of two untuk siswa kelas VIII SMP Negeri 3 Mataram lebih baik digunakan dari model pembelajaran langsung. Hasil penelitian ini sejalan dengan penelitian yang dilakukan oleh Fatmawati (2015), yaitu rata-rata hasil belajar siswa lebih baik yang menggunakan model pembelajaran kooperatif tipe the power of two (Fatmawati et al., 2014). Selain itu hasil penelitian oleh Nurmalia dan Fabelia Andani Barutu (2019), yaitu rata-rata hasil belajar matematika kelas eksperimen lebih 
baik dari pada rata-rata hasil belajar matematika kelas kontrol (Nurmalia \& Barutu, 2019).

Hasil penelitian ini juga mengungkap kelebihan dan kekurangan dari model kooperatif tipe the power of two yang telah diterapkan. Berdasarkan hasil pembelajaran di kelas eksperimen, dapat dikatakan bahwa kelebihan dan keurangan model ini sesuai dengan pernyataan (Ihwanah, 2016). Siswa tidak mengggantungkan guru, akan tetapi dapat menambah kepercayaan kemampuan berfikir sendiri, menemukan informasi dari berbagai sumber dan belajar dari siswa lain, mengembangkan kemampuan mengungkapkan ide atau gagasan dengan kata-kata secara verbal dan dengan membandingkan ide-ide atau gagasan-gagasan orang lain, membantu anak agar dapat berkerja sama dengan orang lain, dan menyadari segala keterbatasannya serta menerima segala kekurangannya, membantu siswa untuk lebih bertanggung jawab dalam melaksanakan tugasnya, Meningkatkan motivasi dan memberikan rangsangan untuk berpikir, dan meningkatkan prestasi akademik sekaligus kemampuan sosial.

Sedangkan, kekurangan model kooperatif tipe the power of two diantaranya yaitu dengan adanya pembagian kelompok secara berpasang-pasangan dan sering antar pasangan membuat pembelajaran kurang kondusif, saat diskusi kelas terkadang didominasi seseorang, hal ini mengakibatkan siwa yang lain menjadi pasif, membutuhkan waktu yang cukup lama dalam penerapannya, dengan adanya kelompok, siswa yang kurang bertanggung jawab dalam tugas, dan membuat mereka lebih mengandalkan pasangannya sehingga mereka bermain-main sendiri tanpa mau mengerjakan tugas.

\section{SIMPULAN}

Berdasarkan data hasil penelitian dan pembahasan yang telah dibahas sebelumnya, dapat disimpulkan bahwa nilai rata-rata kelas eksperimen yang diterapkan menggunakan model pembelajaran kooperatif tipethe power of two lebih tinggi daripada nilai rata-rata kelas kontrol yang diterapkan model pembelajaran langsung. Hal ini menunjukkan bahwa pembelajaran dengan model pembelajaran kooperatif tipe the power of two berpengaruh terhadap hasil belajar matematika siswa kelasVIII SMP Negeri 3 Mataram tahun pelajaran 2019/2020. Hal ini dapat terlihat dari hasil analisis data dimana nilai rata-rata kelas eksperimen lebih tinggi daripada nilai rata-rata kelas kontrol.

\section{REFERENSI}

Daryanto \& Rahardjo, M. (2012). Model pembelajaran inovatif. Gava Media.

Fatmawati, F., Deswita, H., \& Richardo, R. (2014). Pengaruh Model Pembelajaran Kooperatif Tipe the Power of Two Terhadap Hasil Belajar Matematika Siswa Kelas VII SMP N 1 Kepenuhan Hulu. Jurnal Penelitian Universitas Pasir Pengairan, 1(1), 51-56.

Thwanah, A. (2016). Strategi the power of two dan implikasinya terhadap efektivitas pembelajaran Madrasah Ibtidaiyah. Jurnal Tarbiyatuna, 7(1), 103-118.

Nurmalia \& Barutu, F. A. (2019). Pengaruh model pembelajaran kooperatif tipe the power of two 
terhadap hasil belajar siswa kelas VII SMP Negeri 2 Tebing Tinggi, Kabupaten Kepulauan Meranti. Jurnal Online Mahasiswa Pendidikan Matematika (JOMPEMA), 1(1), 102-123. https://doi.org/10.103144/ojm.v1i1

Sanjaya, W. (2015). Penelitian pendidikan jenis, metode dan prosedur. Prenadamedia grup.

Silberman, M. L. (2014). Active learning 101 cara belajar siswa aktif (edisi revisi). Nuansa Cendekia.

Siregar, N. R. (2017). Persepsi siswa pada pelajaran matematika: studi pendahuluan pada siswa yang menyenangi game. Prosiding Temu Ilmiah Nasional X Ikatan Psikologi Perkembangan Indonesia, 1, 224-232.

Slavin, R. E. (2005). Cooperative learning: theory, research, and practice. Nusa Media. 